九州大学学術情報リポジトリ

Kyushu University Institutional Repository

\title{
Design of a Solar AC System Including a PCM Storage for Sustainable Resorts in Tropical Region
}

Byrne, Paul

Laboratoire Génie Civil Génie Mécanique, Université de Rennes

Putra, Nandy

Universitas Indonesia

Maré, Thierry

Laboratoire Génie Civil Génie Mécanique, Université de Rennes

Abdal lah, Nasrudd in

Universitas Indonesia

他

https://doi.org/10.5109/2321009

出版情報：Evergreen. 6 (2)，pp.143-148，2019-06. 九州大学グリーンテクノロジー研究教育センター バージョン：

権利関係 : 


\title{
Design of a Solar AC System Including a PCM Storage for Sustainable Resorts in Tropical Region
}

\author{
Paul Byrne ${ }^{1}$, Nandy Putra ${ }^{2}$, Thierry Maré ${ }^{1 *}$, Nasruddin Abdallah², Pascal Lalanne ${ }^{3}$, \\ Idrus Alhamid ${ }^{2}$, Patrice Estelle ${ }^{1}$, Ardiyansyah Yatim ${ }^{2}$, Anne-Lise Tiffonnet ${ }^{4}$ \\ ${ }^{1}$ Laboratoire Génie Civil Génie Mécanique, Université de Rennes, France \\ ${ }^{2}$ UI, Depok, Indonesia \\ ${ }^{3}$ Turtle reef nature sanctuary, Bali and Lombok, Indonesia \\ ${ }^{4}$ LUSAC, Université de Caen Normandie, France \\ *Author to whom correspondence should be addressed, \\ E-mail: paul.byrne@univ-rennes1.fr
}

(Received November 15, 2018; accepted March 26, 2019)

\begin{abstract}
Environmental concerns worldwide (climate change, global warming, etc.) are pushing to reduce the consumption of fossil fuels. The building sector is responsible for a third of greenhouse gas emissions (40\% in France). In tropical countries, the main share of energy consumption in buildings is due to air conditioning systems. Indeed, in a resort of high standing, $60 \%$ of energy consumption is due to air conditioning. In the Indonesian context, which welcomes growing real estate projects on more or less isolated islands, it becomes important to put in place passive or autonomous buildings and the corresponding energy solutions. The energy efficiency of buildings is based on two pillars: an efficient building's design and on the effectiveness of the air conditioning system to achieve energy independency in a tropical environment. Considering the decreasing cost of PV cells, the solution to reduce the energy consumption of air conditioning proposed in this article covers a vapour-compression refrigeration system electrically powered by solar cells. To avoid the use of electric batteries, not sustainable in terms of carbon footprint (construction and recycling of batteries) and to overcome the problem of intermittency of solar energy, the choice fell on a variable speed compressor and a storage in a mixture of fatty acids (derived from coconut oil) as phase change material embedded in expanded graphite. The work also focuses on the energy performance of the storage system. This study describes the context and the air conditioning system chosen as a solution for a sustainable resort application in a tropical region. The design and characterization of the coupled PCM and compressed expanded graphite in a latent heat thermal energy storage is also detailed. It uses a TRNSYS simulation for the assessment of the cooling demand. Calculations for a prototype of $25 \mathrm{~m}^{2}$ apartment showed that with a chiller of $8000 \mathrm{~W}$ and a surface of $14 \mathrm{~m}^{2}$ of photovoltaic panels, it is possible to cool a hotel bedroom with solar energy. The consortium members work jointly at designing and optimizing the system: Indonesian members are focused on the PCM storage and French members are more dedicated to the hygrothermal behaviour of the hotel bedrooms.
\end{abstract}

Keywords: air conditioning, hotel, net-zero energy, PCM.

\section{Introduction}

Environmental concerns worldwide (climate change, global warming, etc.), are pushing to reduce the consumption of fossil energy. The building sector is responsible for a third of greenhouse gas emissions (40\% in France). In tropical countries, the impact of energy consumption in buildings is mainly due to the air conditioning systems. Indeed, in a resort of high standing, $60 \%$ of energy consumption is due to air conditioning.

In the Indonesian context, showing many new resort projects, especially in islands, it becomes important to investigate passive or autonomous buildings and efficient energy solutions. Energy efficiency of buildings is based on two pillars, an adapted design of the building to reduce expenses and save energy (insulation, materials, orientation, inertia, solar protection, natural ventilation, etc. $)^{1)}$, and on the efficiency of the air conditioning system (if possible renewable energy source, energy recovery, management and regulatory strategy ${ }^{2 / 3 / 4) 5}$.

To reach energy independency with an air conditioning system, some solutions are solar cooling, either absorption or adsorption ${ }^{6}$, or a standard system 
powered by a photovoltaic field ${ }^{7) 899}$. Because of the intermittency and variability of the solar incident radiation during the day most of the studies use electric batteries as an energy storage. Many studies use the temperature difference between day and night by coupling of the air conditioning system with a cold latent heat storage. With a storage during the day and a use overnight ${ }^{10) 11)}$ the system shows energy savings of $9 \%$.

The adaptation of an autonomous air conditioning system for the case of a tropical climate with a small difference between day and night temperatures does not seem to be addressed. Considering the decreasing cost of PV cells, the solution proposed in this article covers a compression refrigeration system electrically powered by solar cells. To avoid the addition of electric batteries, not sustainable in terms of environmental footprint (construction and recycling of batteries) and to overcome the problem of intermittency of solar energy, the choice fell on a variable speed compressor and a storage by phase change materials.

The results present on an annual basis and during a week, internal temperatures, humidity and energy demands. Characteristics of the materials, windows, ventilation, infiltration, internal contributions and occupation scenario are taken into account in the dynamic simulation of the behaviour of the building based on meteorological data. The study is conducted with TRNSYS software ${ }^{12)}$. Results without energy storage are presented and conception and the optimisation of the PCM storage solution is discussed.

\section{System sizing}

\subsection{Assumptions}

This study is based on a project of construction of standard hotel on the island of Lombok in Indonesia. The hotel is a troglodytic construction of 51 luxury apartments of $180 \mathrm{~m}^{2}$ and a common area for reception and restaurants. The climate of this region is tropical humid. The seasonal variation of the temperature being imperceptible, the ground temperature will be assumed constant and equal to the average annual temperature of the outside air, which is $27.32{ }^{\circ} \mathrm{C}$.

All apartments have similar characteristics and the assumptions taken into account are the following:

- front length of $12 \mathrm{~m}$,

- depth of $15 \mathrm{~m}$,

- $180 \mathrm{~m}^{2}$ of floor area,

- $\quad$ ceiling height of $2.7 \mathrm{~m}$,

- façade is fully glazed; glazing of a $23.5 \mathrm{~m}^{2}$.

Due to the thickness of the walls, transfers between apartments or from apartments towards the outside by the opaque walls are supposed to be equivalent to heat transfer towards the ground in a semi-infinite medium. The simulation of the outdoor side of the wall boundary condition is a constant equal to the ground temperature after the layer. Vertical walls, the floor and ceiling are made of the same materials (table 1): inner insulation of glass wool type, concrete and a layer of ground. The energy conservation equation is applied to every layer of material and indoor air.

$$
\mathrm{mCp} \frac{d T}{d t}=\dot{Q}_{\text {in }}-\dot{Q}_{\text {out }}
$$

With $\mathrm{m}$, the material mass, $\mathrm{Cp}$, the specific heat, $\mathrm{dT} / \mathrm{dt}$ the temperature variation with time and $\dot{Q}$, the thermal capacity that can be a cooling capacity, a solar radiation, external gains through walls or internal gains due to electric appliances, lighting and occupancy.

To simplify the model, reception and restaurant zones are not taken into account in the study and only one apartment is modelled.

\begin{tabular}{|c|c|c|c|c|}
\hline & $\begin{array}{l}\text { Width } \\
\text { (cm) }\end{array}$ & $\begin{array}{l}\text { Density } \\
\left({\left.\text { kg. } m^{-3}\right)}^{-1}\right.\end{array}$ & $\begin{array}{l}\text { Conductivity } \\
\left(W \cdot m^{-1} \cdot K^{-1}\right)\end{array}$ & $\begin{array}{l}\text { Heat } \\
\text { capacity } \\
\left(\text { J.kg }^{-1} . K^{-1}\right)\end{array}$ \\
\hline \multirow{3}{*}{$\begin{array}{l}\text { Ground } \\
\text { Insulation } \\
\text { Concrete }\end{array}$} & 30 & 1750 & 1.75 & 1800 \\
\hline & 5 & 20 & 0.035 & 1000 \\
\hline & 20 & 2300 & 1.75 & 1000 \\
\hline
\end{tabular}

Modelled glazing are of double glazing lowemissivity argon-filled with a heat transfer coefficient $\mathrm{U}_{\mathrm{w}}$ of $1.43 \mathrm{~W} \cdot \mathrm{m}^{-2} \cdot \mathrm{K}^{-1}$ and a solar g-factor 0.596 . Glazing with carpentry wood without opening are chosen. To avoid disrupting of the air conditioning effect two solid wood doors will allow the passage of the occupants.

Following the rules of calculation NF $52-612 / \mathrm{CN}$, the air renewal through the ventilation rate is 0.617 $\mathrm{vol} / \mathrm{h}$. This corresponds to a flow of around $300 \mathrm{~m}^{3} / \mathrm{h}$ per apartment. The choice is based on ventilation through air intakes, limiting the renewal during inoccupation of the building.

Air infiltration is neglected in the case of troglodytic dwellings. Internal gains in the apartments are modelled by the thermal powers produced by occupants, lighting and electric equipment (refrigerator, TV...) associated with a scenario of occupation. The powers and scenarios are listed in table 2 .

TABLE 2: Internal power by apartment.

\begin{tabular}{l|l|l} 
Type of power & Power $(\boldsymbol{W})$ & Scenarios \\
\hline Occupants & $\begin{array}{l}2 \text { persons } 150 \mathrm{~W} \\
=300 \mathrm{~W}\end{array}$ & From 6pm to 9am \\
\hline Lighting & $\begin{array}{l}5 \mathrm{~W} / \mathrm{m}^{2} \\
\text { e.g. } 900 \mathrm{~W}\end{array}$ & $\begin{array}{l}\text { From } 6 \mathrm{pm} \text { to } 11 \mathrm{pm} \text { and } \\
7 \mathrm{am} \text { to } 9 \mathrm{am}\end{array}$ \\
\hline Equipment & $300 \mathrm{~W}$ & $\begin{array}{l}\text { Constant or from } 6 \mathrm{pm} \\
\text { to 9am occupants }\end{array}$ \\
\hline
\end{tabular}

\subsection{Results}

Developments outside temperature, relative humidity and the global sunshine taken into account in our study are extracted from the Trnsys documentation and presented on the following figures (Figure 1).

In the light of these results, for one apartment, annual cooling demand would be $22135 \mathrm{kWh}$ considering an average power of $2526 \mathrm{~W}$ and a maximum instantaneous power of $6737 \mathrm{~W}$. 


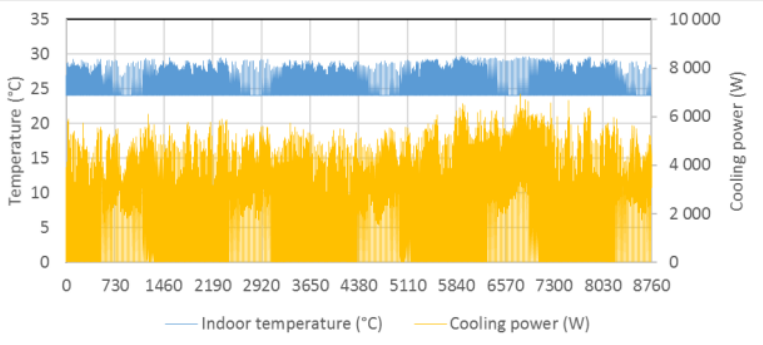

FIGURE 1: Evolutions of internal temperature and thermal power inlet during one year for one apartment

The operation on the first week of simulation is presented in Figure 2 for all apartments. This simulation considers centralized cooling system powered directly by photovoltaic solar panels. The refrigerating machine has a variable speed compressor with a coefficient of performance COP equal to 3 . The frequency of rotation varies depending on the intensity of the current produced by the solar panels, depending on the solar radiation absorbed by the photovoltaic field.

The rest of the annual simulation observes a similar behavior. The evolution of the outside temperature is described by the blue curve. The temperature varies between 23 and $33{ }^{\circ} \mathrm{C}$. Cold needs depend on this temperature, internal contributions (dark grey curve) and solar (brown curve). Solar gains are slightly delayed from the cooling power (yellow line) because the orientation of the glazing towards the East. The cooling system lowers the indoor temperature (orange curve) in the rooms when the solar radiation hits the photovoltaic panels. When there is more radiation, the temperature increases because of internal contributions due to the arrival of the occupants and a higher outdoor temperature at the end of day.

The evolution of the interior temperature can be compared to the one that would be obtained without cooling system (grey curve). The inside temperature obtained with this AC system directly powered by solar panels can reduce the indoor temperature without reaching the desired point of $24{ }^{\circ} \mathrm{C}$ during occupation. Temperatures fluctuate between 27 and $28{ }^{\circ} \mathrm{C}$. The solution that consists to use electrical batteries is considered as expensive and having a strong environmental impact. The less expensive solution left is to use a storage tank containing a PCM (phase change material).

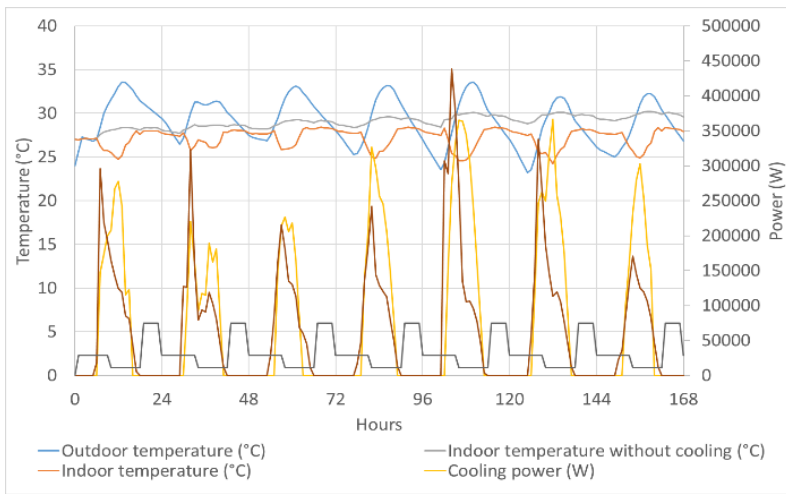

FIGURE 2: Temperature and power evolutions over a week

\section{System design}

\subsection{Operating scenario}

The operation principle is shown in figure 3 . The cold production is driven by the solar resource as long as the temperature in the building is above $24{ }^{\circ} \mathrm{C}$. During the morning and early in the afternoon, direct cooling is carried out. When the temperature set point is reached and solar radiation is sufficient, the surplus of energy is used to produce and store cooling energy in the PCM. During the first hours of the night, the PCM storage is discharging. During the end of the night, the cooling energy is expected to be brought freely by over-ventilation with fresh air. The building thermal inertia should also participate to limit the indoor temperature increase due to internal gains. Figure 3 shows the general operational scheme. The simultaneous case of direct air conditioning and cold storage in the tank is possible. The circulating pumps will be supplied with PV electricity. The water of the swimming pool is used as a heat sink for the cooling system. The condenser is thus a plate heat exchanger. The water temperature is assumed constant and equal to $30{ }^{\circ} \mathrm{C}$.

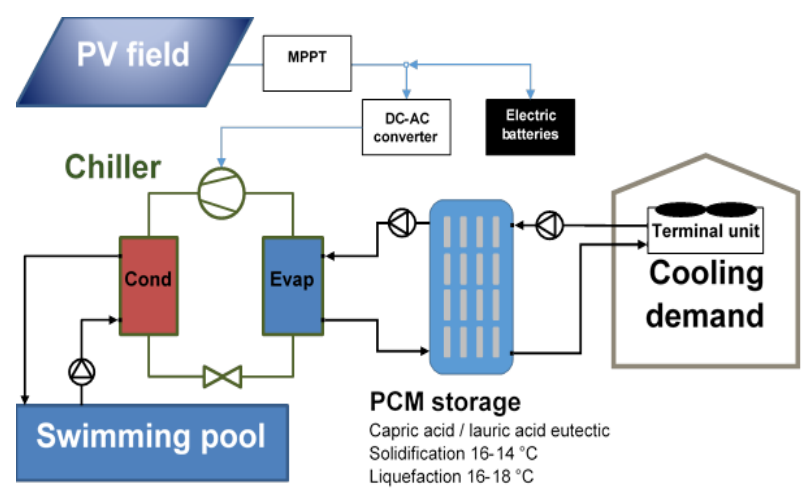

FIGURE 3. Operation principle

\subsection{PCM characteristics}

Different techniques are used, either by microencapsulation in a water circuit or by macroencapsulation in a storage tank ${ }^{13) 14) 15)}$. The phase change materials used can be classified into three categories: organic (paraffins or not), inorganic (salt hydrates), eutectic mixtures (organic or inorganic).

The selection criteria of these materials are the melting temperature, the latent heat, the cost, the density (amount of storage), the vapour pressure (as low as possible), the dangerousness, the reliability of containment materials, supercooling stability (as low as possible $)^{16)}$. Most of the eutectic have a melting point between 20 and $60^{\circ} \mathrm{C}$ and a latent heat between 125 and $200 \mathrm{~kJ} / \mathrm{kg}$. The majority of organic PCMs are of paraffins and fatty acids. Paraffins show good thermal and chemical stabilities ${ }^{17) 18) 19) 20)}$.

The selected PCM for our study is a eutectic mixture of $73 \%$ of capric acid (decanoic) and $27 \%$ of lauric acid (dodecanedioic) in molar compositions. It has a melting temperature around $18{ }^{\circ} \mathrm{C}^{21)}$. The 
composition of the eutectic mixture has been questioned and approved by Longfei and $\mathrm{al}^{22)}$. The main reason for this choice of PCM is that these fatty acids come from coconut oil. This is commercial and environmentally friendly. The problem is that the solidification temperature is low and presents a big hysteresis. To reduce the temperature of solidification, the impact of a surfactant was tested ${ }^{23)}$.

\subsection{Experimental set-up}

A volume of $300 \mathrm{ml}$ of coconut oil with a temperature of fusion of $18{ }^{\circ} \mathrm{C}$ was placed in a refrigerator at temperature of $-10{ }^{\circ} \mathrm{C}$. The environment temperature was $28^{\circ} \mathrm{C}$. A type $\mathrm{K}$ thermocouple with an accuracy of $0.1{ }^{\circ} \mathrm{C}$ was placed in the centre and an acquisition was used to record the temperature evolution. To improve the mixing of the surfactant and the coconut oil, some water was added to the mixture. This addition reduces the mass of phase change material. To decrease the melting temperature, additions of $5 \%$ and $10 \%$ percentage of surfactant (sodium laurate) were tested. Figure $4 \mathrm{a}$ and $4 \mathrm{~b}$ show the temperature evolutions during cooling-down and heating-up processes.
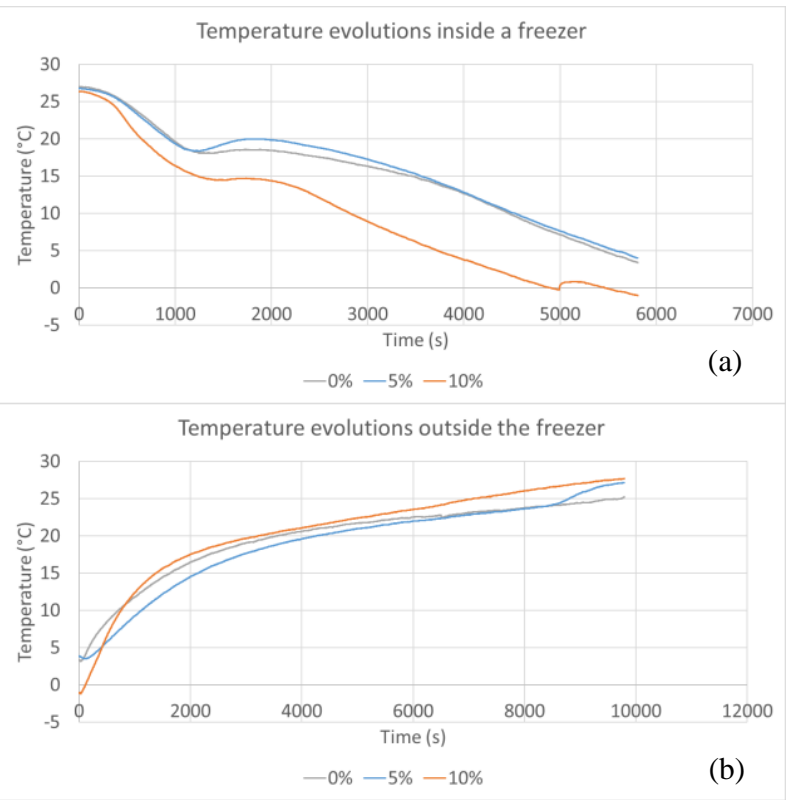

FIGURE 4: Temperature evolutions during (a) coolingdown and (b) heating-up processes.

As expected from the literature review, sodium laurate reduces the solidification temperature by $4 \mathrm{~K}$ for the supposed well-mixed solution. After coming back to initial temperature, the $5 \%$ sample abnormally shows two phases, one white and the other transparent. The $10 \%$ mixture seems almost homogeneous. Therefore, our final PCM choice is a mixture of capric acid (decanoic) $73 \%$, lauric acid (dodecanedioic) $27 \%$ in molar compositions and $10 \%$ of sodium laurate in mass. The final mass composition is capric acid $63 \%$, lauric acid $27 \%$ and sodium laurate $10 \%$. It has a melting temperature around $18{ }^{\circ} \mathrm{C}$. Its latent heat is $140 \mathrm{~kJ} / \mathrm{kg}$.

\subsection{Calculation of energy savings}

These calculations are based on a bedroom prototype built in Bali Indonesia. Figure 5 shows photographs of the project site. Figure 6 presents the layout diagram of the apartment and the energy flows. The bed is in limestone and the bathroom is placed behind the bed. The features of this case study include a vertical wall of $31.25 \mathrm{~m}^{2}$, a floor of $25 \mathrm{~m}^{2}$, a ceiling of $25 \mathrm{~m}^{2}$, a glazing of $4.6 \mathrm{~m}^{2}$, a wall supporting the window of $5,4 \mathrm{~m}^{2}$. The troglodytic room is considered without insulation with a conductivity of $1.7 \mathrm{~W} / \mathrm{mK}$. The ratio of fresh air renewal is $15 \mathrm{~m}^{3} / \mathrm{h}$ during day and night, 2 occupants produce $240 \mathrm{~W}$, electric devices produce continuously $300 \mathrm{~W}$ and LED lights produce $1.5 \mathrm{~W} / \mathrm{m}^{2}$. The glass being East-facing surface, a calculation of solar gain is represented in figure 7 between 6 am to $12 \mathrm{am}$.

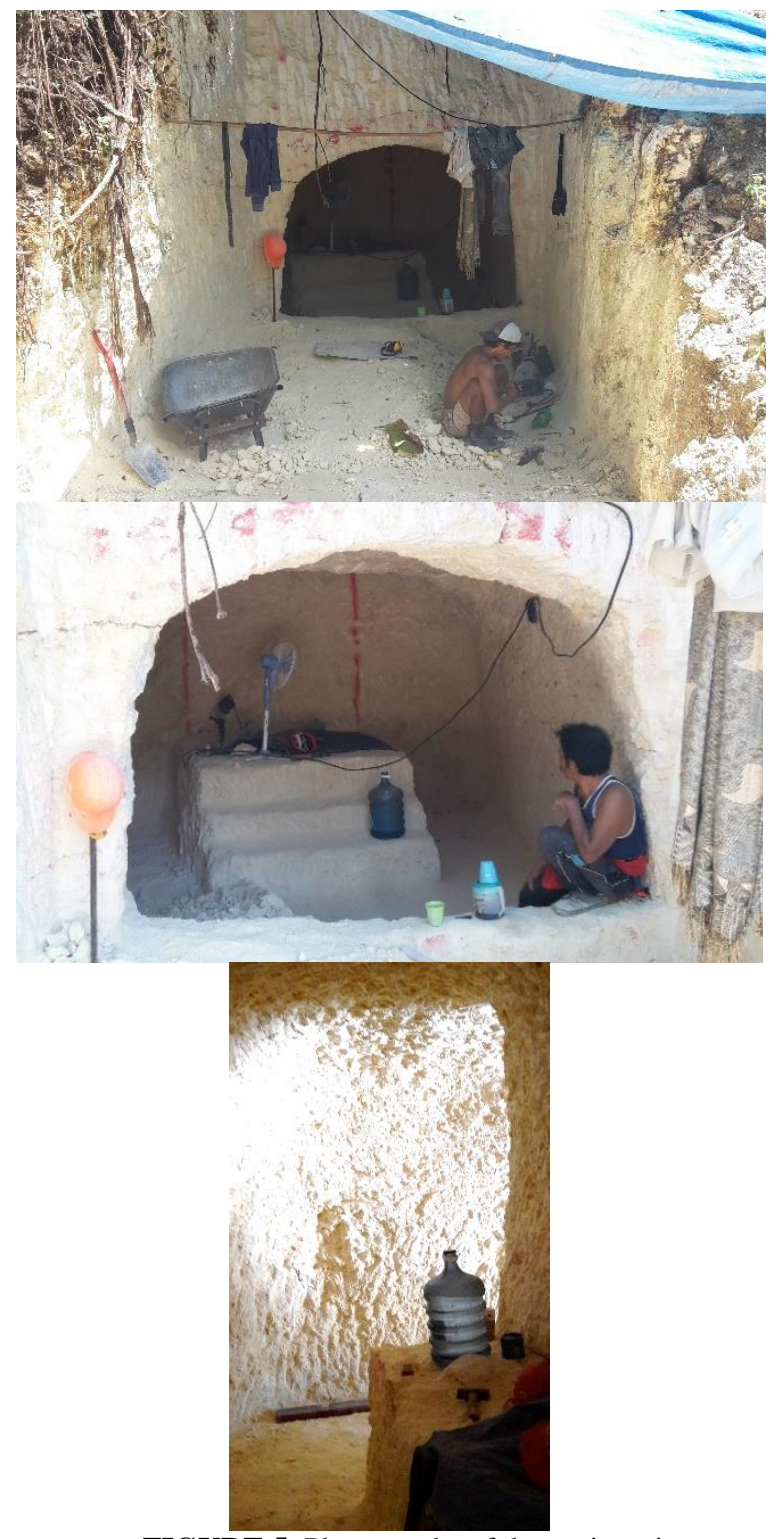

FIGURE 5: Photographs of the project site 


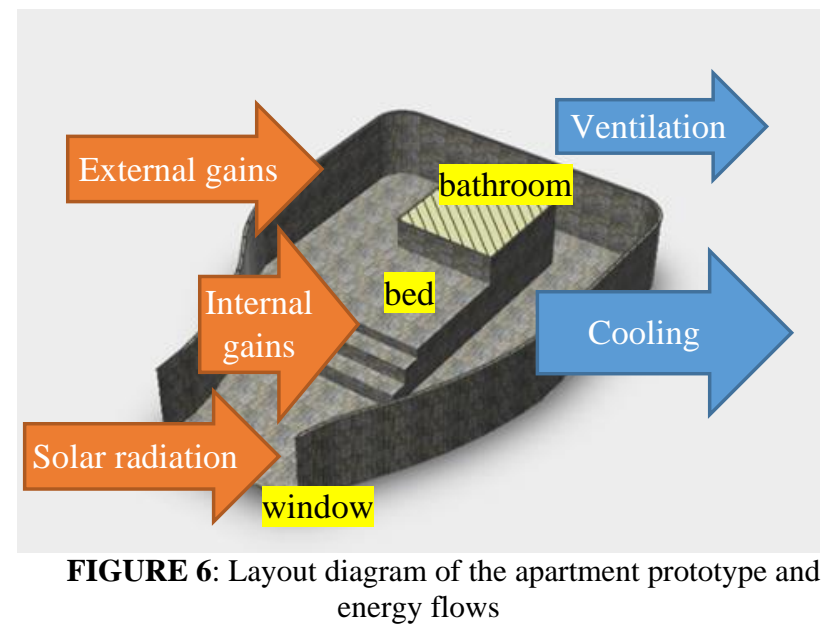

The heat losses through the walls are calculated following French thermal regulation:

$\emptyset=1.45 \sum \mathrm{Ueq} * \mathrm{~A}(\mathrm{Ti}-\mathrm{Te})$

With $\emptyset$ flux in W, A area in $\mathrm{m}^{2}$, Ti inside temperature considered at $23{ }^{\circ} \mathrm{C}$ and $28.5^{\circ} \mathrm{C}$ for the ground.

$\mathrm{Te}$ outside temperature is sinusoidal with amplitude from $22{ }^{\circ} \mathrm{C}$ to $32{ }^{\circ} \mathrm{C}$ and maximum considered at $6 \mathrm{pm}$.

The wall heat loss coefficient $U e q$ in $\mathrm{W} \cdot \mathrm{m}^{-2} \cdot \mathrm{K}^{-1}$ is:

$$
U e q=\ln \left(\frac{a}{d t}\right) * \frac{2 \lambda}{a}
$$

with $\lambda$, the thermal conductivity in $\mathrm{W} \cdot \mathrm{m}^{-1} \cdot \mathrm{K}^{-1}$

$d t=2 w+0.21 \lambda$

with $\mathrm{w}$, the width of the wall in $\mathrm{m}$ and

$a=\frac{A}{p}+d t$

with $\mathrm{p}$ perimeter in $\mathrm{m}$.

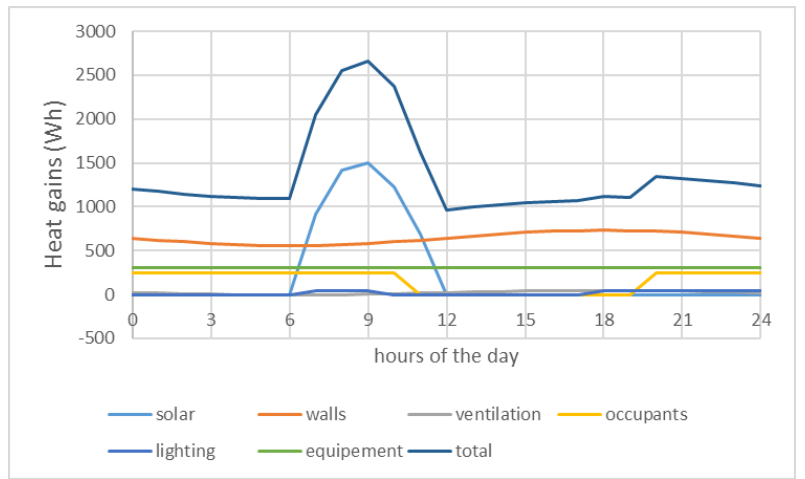

FIGURE 7: Simulation results for heat gains in the troglodytic prototype

Contributions of day and night heat gains represent 34 $\mathrm{kWh}$. The night free cooling input brings $12 \mathrm{kWh}$ of cooling energy, whereas the mass of PCM chosen corresponds to $311 \mathrm{~kg}$. Considering a horizontal photovoltaique sensor (or tilted at 20\%), from 150 $\mathrm{W}_{\text {peak }} / \mathrm{m}^{2}$. A surface of $14 \mathrm{~m}^{2}$ enables to satisfy a maximum cooling demand of $6300 \mathrm{~W}$. A system of cooling power of $8000 \mathrm{~W}$ is chosen allowing to have a maximum hourly rate of operation of $80 \%$. The cooling output and the stored energy evolution is shown in figure 8 .

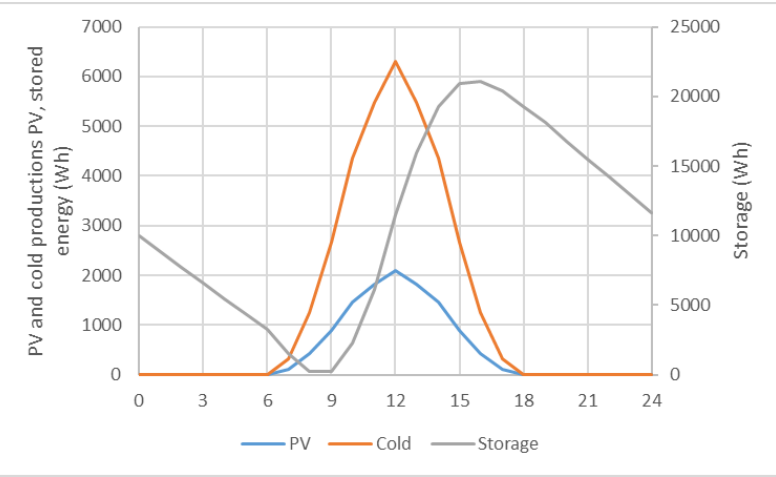

FIGURE 8: Cooling energy production and storage

\section{Conclusion}

A first TRNSYS simulation showed that in a building, a solar dynamic cooling effect is compulsorily linked to a cold storage. The choice was a PCM with a mass composition of $63 \%$ of capric acid (decanoic), of $27 \%$ of lauric acid (dodecanoic) and $10 \%$ of sodium laurate as a surfactant. It has a melting temperature around $18{ }^{\circ} \mathrm{C}$ and a latent heat of 140 $\mathrm{kJ} / \mathrm{kg}$. However, the thermal conductivity being quite low, a heat transfer media will have to be used to enhance the effective thermal conductivity of the latent heat storage system ${ }^{2425)}$. Calculations for a prototype of $25 \mathrm{~m}^{2}$ apartment showed that with a chiller of $8000 \mathrm{~W}$ (corresponding to a running time of $80 \%$ ) and a surface of $14 \mathrm{~m}^{2}$ of photovoltaic panels, it is possible to cool a hotel bedroom with solar energy. The future works will focus on the choice of a heat exchanger for the PCM tank and on the in-situ experimental tests. The authors would like to acknowledge the PHC Nusantara program from the French Embassy in Indonesia who is participating financially to this joint research between France and Indonesia.

\section{Acknowledgements}

The authors would like to acknowledge the PHC Nusantara program from the French Embassy in Indonesia who is participating financially to this joint research between France and Indonesia. The participation of A. Yatim and I. Alhamid in the research is funded by the United States Agency for International Development (USAID) through Scientific Modeling programs, Applications, Research, and Training for City-Centered Innovation and Technology (SMART CITY) - Universitas Indonesia contract no. 0118/UN.2R3.SC/PPM.00/ 2018.

\section{References}

1) S. B. Sadineni, S. Madala, R. F. Boehm, Passive building energy savings: A review of building envelope components, Renewable and Sustainable Energy Reviews, 15, 3617-3631 (2011). 
2) P. Byrne, L. Fournaison, A. Delahaye, Y. Ait Oumeziane, L. Serres, P. Loulergue, A. Szymczyk, D. Mugnier, J.-L. Malaval, R. Bourdais, H. Gueguen, O. Sow, J. Orfi, T. Mare, A review on the coupling of cooling, desalination and solar photovoltaic systems, Renewable and Sustainable Energy Reviews, 47, 703717 (2015).

3) B. Porumb, M. Bălana, R. Porumb, Potential of indirect evaporative cooling to reduce the energy consumption in fresh air conditioning applications, Energy Procedia, 85, 433-441 (2016).

4) X. Zheng, H.-Q. Li, M. Yu, G. Li, Q.-M. Shang, Benefit analysis of air conditioning systems using multiple energy sources in public buildings, Applied Thermal Engineering 107 709-718 (2016).

5) R. Ara Rouf, M. A. Hakim Khan, K. M. Ariful Kabir, B. Baran Saha, Energy Management and Heat Storage for Solar Adsorption Cooling, Evergreen, 3, 1-10 (2016).

6) A. Al-Alili, Y. Hwang, R. Radermacher, Review of solar thermal air conditioning technologies, International Journal of Refrigeration, 39, 4-22 (2014)

7) O. Ekren, S. Celik, B. Noble, R. Krauss, Performance evaluation of a variable speed DC compressor, International Journal of Refrigeration, 36, 745-757 (2013).

8) F. Meunier, D. Mugnier, La climatisation solaire Thermique ou photovoltaïque, Dunod (8 mai 2013)

9) R. Opoku, S. Anane, I.A. Edwin, M.S. Adaramola, R. Seidu, Comparative techno-economic assessment of converted DC refrigerator and a conventional AC refrigerator both powered by solar PV, International Journal of Refrigeration, 72, 1-11 (2016).

10) J.-P. Dumas, Stockage du froid par chaleur latente, Techniques de l'ingénieur, 10 (July 2002).

11)N. Chaiyat, Energy and economic analysis of a building air-conditioner with a phase change material (PCM), Energy Conversion and Management, 94, 150158 (2015).

12) Solar Energy Laboratory, University of WisconsinMadiso. TRNSYS, A Transient Simulation Program, Reference Manual Volume I (2000).

13) A. F. Regin, S.C. Solanki, J.S. Saini, Heat transfer characteristics of thermal energy storage system using PCM capsules: A review, Renewable and Sustainable Energy Reviews, 12, 2438-2458 (2008).

14)J. Wei, Y. Kawaguchi; S. Hirano, H. Takeuchi, Study on a PCM heat storage system for rapid heat supply, Applied Thermal Engineering, 25, 2903-2920 (2005).

15) A. Waqas, Z. Ud Din, Phase change material (PCM) storage for free cooling of buildings: A review, Renewable and Sustainable Energy Reviews, 18, 607625 (2013).

16) M. K. Rathod, J. Banerjee, Thermal stability of phase change materials used in latent heat energy storage systems: A review, Renewable and Sustainable Energy Reviews, 18, 246-258 (2013).

17)M. Kenisarin, K. Mahkamov, Solar energy storage using phase change materials, Renewable and Sustainable Energy Reviews, 11, 1913-1965 (2007).
18)Z. Zhou, Z. Zhang, J. Zuo, K. Huang, L. Zhang, Phase change materials for solar thermal energy storage in residential buildings in cold climate, Renewable and Sustainable Energy Reviews, 48, (2015) 692-703

19) S. Kamali, Review of free cooling system using phase change material for building, Energy and Buildings, 80, 131-136 (2014).

20) A. A. Al-Abidin, S. Bin Mat, K. Sopian, M.Y. Sulaiman, C.H. Lim, A. Th, Review of thermal energy storage for air conditioning systems, Renewable and Sustainable Energy Reviews, 16, 5802-5819 (2012).

21)D. Feldman, M.M. Shapiro, D. Banu, C.J. Fuks, Fatty acids and their mixtures as phase change materials for thermal energy storage, Solar Energy Materials, 18 201-216 (1989).

22)J. Longfei, X. Fengping, Phase diagram of the ternary system lauric acid-capric acidnaphthalene, Thermochimica Acta, 424, 1-5 (2004).

23)H. Fauzi, H.S.C. Metselaar, T.M.I. Mahlia, M. Silakhori, Sodium laurate enhancements the thermal properties and thermal conductivity of eutectic fatty acid as phase change material (PCM), Solar Energy, 102, 333-337 (2014).

24)H. Badenhorst, A review of the application of carbon materials in solar thermal energy storage, Solar Energy, In press, corrected proof (2018).

25) Y. Lin, Y. Jia, G. Alva, G. Fang, Review on thermal conductivity enhancement, thermal properties and applications of phase change materials in thermal energy storage, Renewable and Sustainable Energy Reviews, 82, 2730-2742 (2018). 